\title{
Job Mobility and Subjective Well-being in Europe. Do Highly Mobile Workers Feel Worse?*,1
}

\author{
Movilidad laboral y bienestar subjetivo en Europa. ¿Se sienten peor los \\ trabajadores con elevada movilidad?
}

\author{
Gerardo Meil ${ }^{2}$ and Pedro Romero-Balsas ${ }^{3}$ \\ Universidad Autónoma de Madrid \\ gerardo.meil@uam.es / pedro.romero@uam.es
}

doi: http://dx.doi.org/10.18543/ced-56-2017pp105-131

Contents: I. Introduction.-II. Geographical job mobility and subjective well-being. 1. Subjective well-being as an object of scientific study. 2. Studies of the effects of geographical mobility on subjective well-being. 3. Hypotheses for analysis. - III. Database, operationalisation and analytical strategy.-IV. Results. 1. Changes in mobility patterns. 2. Changes in subjective perceptions of well-being. 3. Impact of geographical mobility on subjective well-being controlling for the effects of other life transitions and the benefits of geographical mobility.-V. Conclusions.

\footnotetext{
Abstract: One of the consequences of globalisation is an increase in the working population's geographical mobility. This mobility can have important effects for individuals, both positively and negatively, on well-being. Based on both waves of the survey Job Mobilities and Family Life (2007 and 2011), we will discuss the impact of entering, leaving and staying in mobility compared to not being mobile on subjective well-being, controlling for other relevant transitions in life (partnership, parenthood, health and financial situation), as well as gender. As analytic strategy we will use OLS regression models of the changes between both waves of four SWB indicators. Results show that SWB indicators have changed for most of the

* Recibido el 4 de febrero de 2017, aceptado el 6 de marzo de 2017.

1 This article is based on a paper published in Revista del Ministerio de Empleo y Seguridad Social, issue 116, 2015, pp. 215-232, under the title "Transiciones de entrada y salida en la movilidad geográfica circular y bienestar subjetivo". The article began to come together at the Bundesinstitut für Bevölkerungsforschung, Wiesbaden, where researcher Katharina Michels participated in the paper's initial phase, contributing discussions and proposals for which we are grateful. The funding for the project steams in part from the Spanish Ministry of Finance and Competitiveness, project reference CSO2010-10800-E and the European Union's Sixth Framework Programme, contract number 028349.

2 ORCID ID 0000-0002-4880-5137

3 ORCID ID 0000-0003-2497-7927
} 
interviewed persons during the period under observation. These changes are not all random, but are related in different degree with the variables under analysis. Whilst satisfaction with work is related with mobility transitions in the expected direction, in the case of life satisfaction the impact of spatial mobility operates mainly through its impact on job satisfaction, which in turn depends on the balance of advantages and cost derived from mobility. In the case of stress, no clear relationship with mobility patterns can be identified once controlled for other relevant variables.

Keywords: work mobility, subjective well-being, stress because of work, work satisfaction, satisfaction with life.

Resumen: Una de las consecuencias de la globalización es el aumento de la movilidad por motivos de trabajo. Esta movilidad tiene efectos positivos y negativos sobre el bienestar de las personas. Basándonos en las dos oleadas (2007 y 2011) de la encuesta Job Mobilities and Family Life, se analizará el impacto que tienen las transiciones en la movilidad sobre el bienestar subjetivo, controlando la influencia de otras transiciones vitales relevantes (pareja, parentalidad, salud e ingresos) así como el sexo. El análisis se basa en la técnica de la regresión lineal ordinaria. Los resultados evidencian generalizados cambios en los niveles de estrés y satisfacción. Estos cambios no son todos aleatorios, sino que guardan relación con las transiciones en la movilidad y demás variables consideradas. Mientras que los cambios en la satisfacción con el trabajo están condicionados por las transiciones en la movilidad en la dirección esperada, los efectos sobre la satisfacción con la vida en general dependen más de los efectos sobre la satisfacción con el trabajo en función de las ventajas e inconvenientes de la movilidad. En el caso de los niveles de estrés, no se observa una relación clara con la movilidad, una vez controlados otros cambios relevantes.

Palabras clave: movilidad laboral, bienestar subjetivo, estrés laboral, satisfacción con trabajo, satisfacción con la vida.

\section{Introduction}

One of the consequences (and premises) of globalisation, and of European integration, is an increase in the working population's geographical mobility. Factual support for that assertion can be found in the increase in migratory flows over the last twenty years. The demand for job-related geographical mobility (job mobility) does not stem solely from economic imbalances between countries and labour shortfalls in expanding countries. They are also an outcome of the deep-reaching change induced by new approaches to work organisation with the onset of what has come to be known as "flexible capitalism"4. Therefore, the population affected by mobility demands

${ }^{4}$ Richard Sennett, The Corrosion of Character: the personal consequences of work in the new capitalism (New York: Norton, 1998). 
does not comprise migrant workers alone, but also includes the domesticborn working population. In the wake of the economic crisis, workers now accept job mobility more willingly, with a view to either finding a job or improving their career expectations ${ }^{5}$.

These demands for job mobility and workers' adaptation in response need not necessarily appear in the form of migration or change of residence. Demands for job mobility adopt many other forms. For example, with company and value-chain internationalisation, business trips have become more frequent for executives and middle management ${ }^{6}$. The spectacular progress of information technologies has failed to erode the need for personal contact, and business trips have only rise. ${ }^{78}$ Training or work periods at the multinational's parent company and career advancement through secondment to different corporate offices are likewise common. As temporary situations, these movements do not entail migration. It is no longer rare for specialised workers and professionals to have to work on projects or missions far from home for stints of varying duration, during which time they nevertheless remain permanent residents of their home city. The seasonal nature of work in some industries such as tourism also requires temporary relocation as an alternative to migration or as a specific feature of job performance. Although workers who operate under working conditions of this description are not migrants, they also may be classified as mobile workers, because they spend the night away from home very frequently or for long periods of time.

Another alternative to migration as a strategy for adapting to job mobility requirements is acceptance of the cost of long daily commutes. The development of transport infrastructure has made it possible to travel longer distances in less time at a lower cost, whilst the rise in real wages has made the expenditure less of a burden. Socio-economic situations that led forcibly to migration in the recent past can now be coped with by longdistance commuting. For instance, many workers residing in small towns prefer to commute to a larger city daily, even though this means for them

${ }^{5}$ Detlev Lück, and Silvia Ruppenthal, «Insights into Mobile Living: Spread, Appearences and Characteristics» in Causes and Consequences of Job-Related Spatial Mobility in CrossNational Comparison, ed. by Norbert F. Schneider and Beate Collet (Leverkusen: Barbara Budrich Publisher, 2010), 37-65.

${ }^{6}$ James R. Faulconbridge and Jonathan V. Beaverstock, «Geographies of international business travel in the professional service economy» in Mobility and Technology in the Workplace, ed. by Donald Hislop (London and New York: Routledge, 2008), 87-102.

7 Paul Haynes, «Information and Communication Technology and International Business Travel: Mobility Allies?» Mobilities 5-4 (2010): 547- 563, doi:10.1080/17450101.2010.510337

8 Yu-Jin Jeong et al., «The occurrence and frequency of overnight job travel in the USA», Work, employment and society 27-1 (2013): 138-152, doi: 10.1177/0950017012460328 
that they have to invest a great deal of their time in transit. They do so, because the trade-off enables them to get better jobs at a lower cost of living, whilst remaining in their original environment or in environments where "quality of life" is higher, respectively. Growing job insecurity and rotation also mean that moving house does not always constitute a clearly superior option to long commutes. For this reason and others, although the average speed of transport is increasing, the average amount of time people spend en route also seems to be increasing in various countries ${ }^{9}$. Between 4 and $11 \%$ of European workers have to spend two hours or more a day commuting at least three days a week ${ }^{10}$.

The growing number of women in the job market and the widespread presence of dual-earner couples are also generating mobility demands, as when one partner has promotion possibilities or a workplace distant from the other's workplace. Various mobility solutions might be brought to bear in such situations: one partner might become a long-distance commuter or an overnighter, or the couple could switch to a long-distance relationship, in which both partners have a home of his or her own ${ }^{11}$.

This high recurring work-related mobility (which we shall refer to as "job mobility" or simply "mobility") can have important effects for individuals both positively, in terms of jobs, careers and/or income, and negatively, in multiple dimensions of personal and family well-being. These and other issues formed the foundations for a research project comparing various European countries (Germany, France, Spain, Switzerland, Poland and Belgium) entitled "Job Mobilities and Family Lives in Europe. Modern Mobile Living and Its Relation to Quality of Life" (www.jobmob-andfamlives.eu). The objective of this survey was to identify the scope and characteristics of job mobility across Europe, the willingness to accept it and its impact on different aspects of everyday life and on individual wellbeing. The research was done between 2004 and 2008 and was funded by the European Union's Sixth Framework Programme (contract 028349), resulting in various publications. ${ }^{12}$ Analysis of the data from the first wave

9 Stephanie Vincent-Geslin and Emmanuel Ravalet, (2016), «Determinants of Extreme Commuting. Evidence from Brussels» Journal of Transportation Geography 54 (2016): 240247, doi:10.1016/j.jtrangeo.2016.06.013

${ }_{10}$ Norbert F. Schneider and Gerardo Meil, Mobile Living Across Europe I. Relevance and Diversity of Job-Related Spatial Mobility in Six European Countries (Opladen/Farmington Hills: Barbara Budrich Publishers, 2008).

${ }^{11}$ Ulrich Beck and Elisabeth Beck-Gernsheim, Distant Love (Cambridge: Polity Press, 2013).

12 The principal findings are given, among others, in Schneider and Meil, Mobile Living Across Europe I. Relevance and Diversity of Job-Related Spatial Mobility in Six European Countries and Schneider and Collet, Causes and Consequences of Job-Related Spatial Mobility in Cross-National Comparison. 
of the survey shows negative impact on various indicators of subjective well-being but indicates that the differences with respect to non-highly mobile persons are not so very great ${ }^{13}$. Other studies ${ }^{14}$ claim the same. This limited impact is attributed in part to the rule of selectivity: Those who cannot manage to adjust to high mobility eventually change jobs or move house, so the persons who do have high mobility are primarily those who have managed to adapt to high-mobility working conditions.

The analyses conducted on the basis of the 2007 survey rest on a cross-sectional focus comparing the variables in the study according to job mobility characteristics and controlling for differing socio-economic circumstances. This cross-sectional focus does not, however, throw any light on the impact that starting or ending mobility has on subjective wellbeing, or nor does it reveal if there is a process of gradual adaptation to mobility. To gain a broader outlook on the conditioning factors and effects of job mobility on people's lives, it was decided in 2010 in Germany and in 2011 in Spain, France and Switzerland to re-administer the survey to those participants from 2007 who agreed to be interviewed again in 2010/2011. In this second wave, the same questionnaire as in the first was applied, but the number of questions was increased to gather more-detailed information on the interviewed persons' experience with mobility in their working biography plus other aspects of the consequences of mobility for health and quality of life ${ }^{15}$.

The object of this paper is to analyse the effects of mobility transitions on subjective well-being. More specifically, we analyse the impact of starting and stopping high circular mobility on levels of general stress and work-related stress and on satisfaction with work and with life in general. On one hand, we present descriptive results about the change on subjective well-being indicators. On the other hand, we carry out a multivariate analysis using the linear regression technic in order to control change on subjective well-being by other relevant variables.

${ }^{13}$ Ruth Limmer and Heiko Rüger, «Job Mobilities and Quality of Life» in Causes and Consequences of Job-Related Spatial Mobility in Cross-National Comparison, ed. by Norbert F. Schneider and Beate Collet (Leverkusen: Barbara Budrich Publisher, 2010): 263-288.

14 Alois Stutzer and Bruno S. Frey, «Stress that doesn't pay. The commuting paradox», The Scandinavian Journal of Economics 110-2 (2008): 339-366 doi: 10.1111/j.14679442.2008.00542.x

15 Heiko Rüger et al., Job Mobilities and Family Lives in Europe - Second Wave. Panel Data Set \& Oversampling. (Wiesbaden: Bundesinstitut für Bevölkerungsforschung, 2016). 


\section{Geographical job mobility and subjective well-being}

\section{Subjective well-being as an object of scientific study}

Interest in analysing subjective personal well-being has a long tradition, especially in social psychology ${ }^{16}$. In the economic and sociological analysis of social reality, interest in subjective well-being is more recent. Also, it has grown in popularity as gross domestic product has been called into question as a fitting measurement of how societies and people progress, particularly as a result of the well-known report by Stiglitz, Sen and Fittousi ${ }^{17}$, who recommend that, when evaluating the social progress of societies, we should shift our emphasis and pay attention to assessing not only economic production but also personal well-being. In this context, the demands of multiple social actors for greater geographical mobility on the part of workers to make European societies better able to adapt to changing market conditions, reduce unemployment, beat the crisis and guarantee sustainable development also have to be weighed according to the effects such measures would have on personal well-being. Thus, the objective of this paper is precisely to analyse the impact of geographical mobility transitions on subjective personal well-being.

The concept of subjective well-being has been defined in many ways, although all definitions stress that the category is a broad one that includes peoples' emotional responses to their life situations, peoples' satisfaction with various aspects of the reality in which they live (work, family, friendships, etc.) and an overall assessment of their satisfaction with life ${ }^{18}$. That is, subjective well-being includes emotional components or moods (in which both positive and negative aspects are included) and rational assessments of different aspects of one's life, but not objective situations as such (as do approaches centring on "quality of life"). Other authors also include another dimension referring to what they call "eudaimonic well-being", which includes personal traits like self-esteem and a sense of autonomy, social relations and certain external conditions ${ }^{19}$. So, a multitude of definitions exists about what constitutes subjective well-being, as do a

16 Ed Diener et al., «Subjective well-being: Three decades of progress» Psychological Review 5-1 (1999): 1-31.

17 Joseph Stiglitz, Amartia Sen, and Jean-Paul Fittousi, Report by the Commission on the Measurement of Economic Performance and Social Progress (Paris, 2009) available in http:// www .stiglitz-sen-fitoussi.fr/en/index.htm.

18 Diener et al., «Subjective well-being: Three decades of progress», 1-31.

19 Eurofound, Third European Quality of Life Survey - Quality of life in Europe: Subjective well-being, (Luxembourg: Publications Office of the European Union, 2013). 
multitude of ways of measuring it. As a result, many studies fundamentally use indicators that generally assess satisfaction with life, happiness or satisfaction with some particular aspect of life, such as work, inasmuch as these are the habitual indicators included in surveys. Comparability with future studies can thus be facilitated.

\section{Studies of the effects of geographical mobility on subjective well-being}

Despite the profusion of studies on the factors on which subjective well-being hinges, studies focusing on the effects of geographical mobility are comparatively scarce ${ }^{20}$. Studies conducted in the United States show that commuting time creates stress ${ }^{21}$. This same relationship between long commuting times and stress has been found also for Germany 2223 and $\mathrm{Canada}^{24}$, although for Sweden ${ }^{25}$ it is reported that feelings during commuting are predominantly positive or neutral. There are also studies reporting that this stress has negative effects on health ${ }^{26}{ }^{27}$, satisfaction with life ${ }^{28} 29$ and the quality of partner relations $s^{30}$.

Despite these negative effects, the indicators used in cross-sectional analyses show that the differences between the highly mobile and the nonmobile are not as great as might be expected in terms of the effects on perceived stress levels or in terms of health or satisfaction with work. The

${ }^{20}$ Lars Olsson et al. «Happiness and Satisfaction with Work Commute» Social Indicators Research 111, (2013): 255-263, doi:10.1007/s11205-012-0003-2.

${ }^{21}$ For a a review see Raymond W. Novaco and Oscar I. Gonzales, «Commuting and well-being» in Technology and well-being, ed. by Yair. Amichai-Hamburger (New York: Cambridge University Press, 2009): 174-205.

22 Stutzer and Frey, «Stress that doesn't pay. The commuting paradox», 339-366.

${ }^{23}$ Katrin Roller, «Corporate Mobility: When and Why Does it Become a Burden?», in Sustainable Mobility in Metropolitan Regions ed. by Gebhard Wulfhorst and Stefan Klug (Wiesbaden: Springer, 2016): 65-82.

${ }^{24}$ Martin Turcotte, «Commuting to work: Results of the 2010 General Social Survey», Statistics Canada Catalogue no. 11-008-X (2011), available in http://www.statcan.gc.ca/ pub/11-008-x/2011002/article/11531-eng.pdf

${ }^{25}$ Olsson et al. «Happiness and Satisfaction with Work Commute», 255-263.

${ }^{26}$ Erik Hansson et al., «Relationship between commuting and health outcomes in a crosssectional population survey in southern Sweden» BMC Public Health 11 (2011):834-842, doi: 10.1186/1471-2458-11-834

${ }^{27}$ Heiko Rüger et al., «Fernpendeln und gesundheit. Gibt es Hinweise auf einen ,healthy commuter effect?», Arbeitsmedizin Sozialmedizin Umweltmedizin, 44-3 (2009): 113.

${ }^{28}$ Limmer and Rüger, «Job Mobilities and Quality of Life», 263-288.

29 Stutzer and Frey, «Stress that doesn't pay. The commuting paradox», 339-366.

30 Michael Feldhaus and Monika Schlegel, «Job-Related Circular Mobility and the Quality of Intimate Relationships», Comparative population studies 38-2 (2013): 291-314. 
average amount of satisfaction with life on a ten-point scale ${ }^{31}$ is 7 points for those who spend 55 minutes per day per trip between home and work (a 110-minute round trip) as opposed to 7.1 amongst those who spend 25 minutes per trip and 7.2 amongst those who spend 10 minutes. The differences moreover seem to tend to become statistically insignificant when a high geographical mobility situation becomes long term; a process of selection and adaptation to mobility can be observed, in which those who cannot bear mobility end it by changing jobs or moving house 3233 .

\section{Hypotheses for analysis}

For the persons involved, geographical mobility poses different types of advantages and drawbacks ${ }^{34}$ 35. First, circular geographical mobility expands the possibilities of finding a job, facilitates a career and provides possibilities of increasing one's salary; it may also facilitate a situation in which both partners have remunerated work, or it may avert undesired relocation. Top amongst the disadvantages is the fact that geographical mobility tends to generate an overburdened feeling ${ }^{36}{ }^{37}$, stress ${ }^{38} 3940$, less satisfaction with family life $\mathrm{e}^{41}$ and a perceived loss of control over one's life. Sometimes it generates a feeling of geographical alienation, in the sense of

31 Stutzer and Frey, «Stress that doesn't pay. The commuting paradox», 339-366.

32 Steffen Häfner, Hans Kordy and Horst Kächele, «Psychosozialer Versorgungsbedarf bei Berufspendlern», Psychotherapie Psychosomatik medizinische Psychologie 51 (2001): 55-61.

${ }^{33}$ Limmer and Rüger, «Job Mobilities and Quality of Life», 263-288.

34 Gerardo Meil, «Movilidad geográfica en las biografías laborales: alcance, características y razones para asumirla», Revista del Ministerio de Empleo y Seguridad Social 111 (2014): 17-35.

${ }^{35}$ Heiko Rüger and Silvia Ruppenthal, «Advantages and Disadvantages of Job-Related Spatial Mobility», in Causes and Consequences of Job-Related Spatial Mobility in CrossNational Comparison, ed. by Norbert F. Schneider y Beate Collet (Leverkusen: Barbara Budrich Publisher, 2010): 69-93.

${ }^{36}$ Giovanni Costal, Laurie Pickup and Vittorio Di Martino, «Commuting - a further stress factor for working people: evidence from the European Community», Int. Arch Occup Environ Heath 60-5 (1988): 377-385 doi:10.1007/BF00405674

37 Stutzer and Frey, «Stress that doesn't pay. The commuting paradox», 339-366.

${ }^{38}$ Häfner, Kordy and Kächele, «Psychosozialer Versorgungsbedarf bei Berufspendlern», 55-61.

39 Novaco and Gonzales, «Commuting and well-being», 174-205.

40 Turcotte, «Commuting to work: Results of the 2010 General Social Survey».

${ }^{41}$ Feldhaus and Schlegel, «Job-Related Circular Mobility and the Quality of Intimate Relationships», 291-314. 
feeling that one is not really at home anywhere ${ }^{42}$. Consequently, our first hypothesis is that changes in a circular geographical mobility situation affect the subjective well-being of the persons involved.

In addition to the disadvantages just mentioned, persons with a high circular geographical mobility frequently speak of not having enough time. This prevents them from spending enough time with their family and tends to exacerbate the problem of balancing work and family life ${ }^{4344} 45$. Shortness of time has a negative effect on not only family life, but also the social life of the persons involved, making it harder to maintain social relationships, whether this means friendships or participation in associations for various objectives ${ }^{46}$. This shortness of time can thus further increase perceived stress, as one cannot attend to one's various work-related and private commitments, and it may also lead one to neglect one's health ${ }^{47} 48$. These feelings and perceptions, which may also lead to greater dissatisfaction with life, may nevertheless fade in importance as persons and the members of their social network adapt to the time restrictions placed on them by high geographical mobility. Consequently, our second hypothesis is as follows: Starting mobility entails a decrease in subjective personal well-being.

Whilst those who have high geographical job mobility may develop adaptive strategies enabling them to reduce the disadvantages of mobility, and whilst the advantages of mobility may compensate for the disadvantages, there are studies suggesting that ending mobility entails an improvement in subjective well-being ${ }^{49}{ }^{50}$. Consequently, our third hypothesis is that no longer having to accept high geographical mobility entails an increase in subjective well-being.

42 Rüger and Ruppenthal, «Advantages and Disadvantages of Job-Related Spatial Mobility», 69-93.

43 Gerardo Meil, «Job Mobility and Family Life», in Causes and Consequences of JobRelated Spatial Mobility in Cross-National Comparison, ed. by Norbert F. Schneider y Beate Collet (Leverkusen: Barbara Budrich Publisher, 2010): 215-235.

44 Turcotte, «Commuting to work: Results of the 2010 General Social Survey».

45 Feldhaus and Schlegel, «Job-Related Circular Mobility and the Quality of Intimate Relationships», 291-314.

${ }^{46}$ Heiko Rüger et al., «Sind berufsbedingte räumliche Mobilität und freiwilliges Engagement miteinander vereinbar? Befunde der zweiten Erhebungswelle der Studie „Job Mobilities and Family Lives in Europe“", Bevölkerungsforschung Aktuell 33-6 (2012): 2-9.

${ }^{47}$ Dorothea Nitsche et al., «Berufspendeln und Fehlzeiten. Fehlen Berufspendler häufiger bei der Arbeit? » Arbeitsmedizin Sozialmedizin Umweltmedizin 44-3 (2009): 162- 171.

${ }^{48}$ Meni Koslowsky, Avraham Kluger and Mordechai Reich, Commuting Stress. Causes, Effects, and Methods of Coping (New York: Plenum Press, 1995).

49 Häfner, Kordy and Kächele, «Psychosozialer Versorgungsbedarf bei Berufspendlern», $55-61$.

50 Stutzer and Frey, «Stress that doesn't pay. The commuting paradox», 339-366. 


\section{Database, operationalisation and analytical strategy}

To analyse these questions, our basis will be the two waves of the survey "Job Mobilities and Family Lives in Europe. Modern Mobile Living and Its Relation to Quality of Life" (www.jobmob-and-famlives. eu), applied in 2007 in six European countries (Germany, France, Belgium, Switzerland, Poland and Spain) $)^{51} 52$ and again in 2010 in Germany and in 2011 in Spain, France and Switzerland. Whilst 7,220 interviews were conducted in 2007, drawing on a representative sample of persons aged 25 to 54, with mobile persons over-represented to ensure a minimum of 400 in each of the countries, in 2011 only 1,734 surveys could be taken, because two of the countries initially involved did not participate and because the response rate fell from the level found in 2007 to $47 \%$ in Spain, $44 \%$ in Switzerland, $30 \%$ in Germany and 21\% in France. Altogether, 35\% of the population interviewed in 2007 in these four countries participated in the second wave ${ }^{53}$. Although the sample obtained in 2010/2011 is not statistically representative of the reference population and cannot be used to analyse the evolution of job mobility as a consequence of the economic crisis, it does afford data for an analysis of the mobility experience of the interviewed persons and its impact on different spheres of their life from a longitudinal perspective. For the data analysis, the data are weighted to make the sizes of the national samples equal.

For the purpose of this analysis, persons with job mobility are held to be those persons who have to spend two hours or more commuting (Long Distance Commuters) and/or have to spend 60 nights or more per year away from home for job-related reasons (Overnighters). We term this type of mobility "circular mobility", because, as argued above, it implies not a change of residence, but the regular (daily or otherwise, depending on the circumstances) return to a home located away from the place of work ${ }^{54}$. This definition excludes migrants and persons who have changed their residence, because these persons could not be interviewed in the two waves due to the lack of contact information.

${ }^{51}$ Schneider and Meil, Mobile Living Across Europe I. Relevance and Diversity of JobRelated Spatial Mobility in Six European Countries.

${ }^{52}$ Schneider and Collet, Causes and Consequences of Job-Related Spatial Mobility in Cross-National Comparison.

${ }^{53}$ Rüger et al., Job Mobilities and Family Lives in Europe - Second Wave. Panel Data Set \& Oversampling.

${ }^{54}$ Norbert F. Schneider, Ruth Limmer and Kerstin Ruckdeschel, Mobil, flexibel, gebunden: Familie und Beruf in der mobilen Gesellschaft, (Frankfurt am Main: Campus Verlag, 2002). 
As stated before, "subjective well-being" is a broad, heterogeneous concept. In this paper, on the basis of the information available from the questionnaire administered to the interviewed persons, we use four variables to measure subjective well-being. These variables are changes in work-related stress levels, general stress perceived in the three months prior to the interview, satisfaction with work and satisfaction with life in general. Changes in these indicators are measured by the scoring difference between the 2011 wave and the 2007 wave on a five-point scale for workrelated stress and satisfaction and a ten-point scale for general stress and satisfaction, from low to high. The values these variables take therefore represent not absolute levels of stress or satisfaction at a given point in time, but the changes that occur in the time interval considered. Negative values indicate a decrease in the indicator, whilst positive values represent an increase, and the absence of difference (when the value is " 0 ") means there is no difference between assessments at the two points in time. Whilst table 1 contains all the persons who declared any increase or decrease, regardless of the size of the difference, tables 2 and 3 consider each and every one of the values the difference takes independently.

The first dependent variable we call "change in work stress level". It is constructed on the answers to the question, "Tell me, within the last three months, how often did you feel stressed because of your daily situation?" The answer choices in both waves are never (1), seldom (2), sometimes (3), often (4) and very often (5). The values the variable takes run from -4 to +4 , where the negative values correspond to a decrease in the perceived stress level, and the positive values, an increase in the stress level.

The second variable, which we call "change in general stress level", is constructed pursuant to the same logic as in the case above, on the basis of the answers to the question, "If you think about all aspects of your life, how stressful was your life all in all within the last three months? Please answer on a scale of 1 to 10 , where 1 is not stressful at all and 10 is very stressful." The range of values in this variable's case runs from -9 to +9 , and the negative values correspond in this case also to a decrease in the stress level, whilst the positive values correspond to an increase in the perceived stress level.

The variable "change in satisfaction with work" is constructed on the basis of the answers to the question, "And how satisfied are you with your job situation?" The answer choices are very dissatisfied (1), somewhat dissatisfied (2), somewhat satisfied (3) and very satisfied (4). This variable's range of values runs from -3 to +3 , and negative values represent a decrease in satisfaction, whilst positive values represent an increase in satisfaction.

Lastly, the variable "change in satisfaction with life in general" is constructed similarly to the other variables, on the basis of the answers to 
the question, "All things considered, how satisfied would you say are you with your life within the last three months? Please tell me on a scale of 1 to 10 , where 1 means very dissatisfied and 10 means very satisfied." This variable's range runs from -9 to +9 , and the negative values represent a reduction in satisfaction, whilst the positive values represent an increase in satisfaction.

To analyse the impact of mobility on subjective personal well-being, we considered changes in the circular geographical mobility situation (that is to say, we excluded migration and changes of residence) between the two periods considered. We term these changes "mobility transitions". The options in this sense are four. First, we have 1) those persons who are not mobile in either of the two forms at the points in time under observation. Second, we have 2) those who are mobile in both waves of the survey (we call them "stayers"). In addition to these possibilities, we might also find 3 ) those who become mobile during the period ("starters"), that is, who are not mobile in 2007 but are mobile in 2011, and 4) those who cease to be mobile ("stoppers").

Although the primary objective of this paper is to analyse the impact of geographical mobility transitions on subjective well-being, it is necessary to control for the influence of other variables important to subjective well-being. It is particularly necessary to control for the impact of family transitions, economic situation and health ("love", "wealth" and "health"), as these dimensions are closely related with subjective personal wellbeing 555657 . In addition to these variables, we control also for the gender of the interviewed person, because job mobility is strongly conditioned by gender, primarily due to the additional difficulties introduced by the problem of balancing work and family life ${ }^{58}{ }^{59}$, especially when there are small children in the household.

The dimensions considered with regard to family transitions are, first, partnership transitions and, second, entry into parenthood. The following situations are considered in partnership transitions: 1 . The person has a

55 Mark Rapley, Quality of life research, A critical introduction (London: Sage, 2003).

56 Paul Dolan, Tessa Peasgood, and Mathew White, «Do we really know what makes us happy? A review of the economic literature on the factors associated with subjective wellbeing», Journal of Economic Psychology, 29-1 (2008): 94-122.

57 Eurofound, Third European Quality of Life Survey - Quality of life in Europe: Subjective well-being,

58 Beate Collet, and Andrea Dauber, «Gender and Job Mobility» in Causes and Consequences of Job-Related Spatial Mobility in Cross-National Comparison, ed. by Norbert F. Schneider y Beate Collet (Leverkusen: Barbara Budrich Publisher, 2010): 173- 194.

${ }^{59}$ Feldhaus and Schlegel, «Job-Related Circular Mobility and the Quality of Intimate Relationships», 291-314. 
partner at both points in time, regardless of whether they live together or not; 2 . The person does not have a partner in the first wave of the survey but does in the second; and 3. The person has a partner in the first wave but not in the second. These variables are constructed dichotomously, so the multivariate analysis includes only the second and third variable, making partnership at both points in time the baseline situation. A similar procedure is used with entry into parenthood. Two possible situations are distinguished: 1 . The person does not have children at either point in time and 2. The person has his or her first child during the period. In the multivariate analysis, because this variable too is constructed as dichotomous, only entry into parenthood is entered as a variable; thus, non-parenthood at both points in time is the baseline situation. Parenthood of more than one child is not considered, mostly because of the limited number of cases available.

The interviewed person's income level may change due to a variety of circumstances; an increase in income as a consequence of having accepted high mobility is only one of the many possibilities. To measure income level changes, we use the proxy variable "difference in satisfaction with financial situation". Use of this variable obviates problems of comparability amongst the different salary levels of the various countries in the sample as well as changes over time stemming simply from inflation- and seniority-related salary adjustments. In this sense, we assume that increases in satisfaction reflect improvements in income above the standardised baseline situation as a consequence, for example, of promotion or simple procurement of a job. Economic advantages stemming from geographical mobility, if any, should thus be reflected in an increase in satisfaction with income. This variable is constructed on the basis of the answer to the question, "And how satisfied are you with your financial situation?" The answer choices are very dissatisfied (1), somewhat dissatisfied (2), somewhat satisfied (3) and very satisfied (4), so the variable takes a value of -3 to +3 .

Lastly, to measure changes in health, we fall back upon the subjective perception of health and proceed similarly on the basis of the answers given in the two waves of the survey to the question, "In general, would you say your health is poor, fair, good, very good or excellent?" Changes are measured by the difference in the answers given in 2011 and 2007, so the variable takes a value of between -4 and +4 , where the positive sign indicates an improvement in perceived health and the negative sign, a decline.

To analyse the impact of these variables, first we conducted a bivariate analysis in which the changes in the four subjective well-being indicators that we selected were placed in relationship with transitions in the person's circular geographical mobility situation. Next, to control for the effects 
of the other independent variables considered, we used the statistical technique of ordinary linear regression adjusted by least squares (OLS), which is a suitable technique for measuring simultaneously the significance and direction of the influence of each of the independent variables on each of the dependent variables considered. ${ }^{60} 61$

\section{Results}

\section{Changes in mobility patterns}

Between 2007 and $2011,17 \%$ of the people who agreed to be interviewed in both waves had some kind of mobility experience, because they had a job that required high geographical mobility at both times, because they left mobility at some point in the period or because they had to enter mobility. The most frequent situations were transitions into or out of mobility, rather than long-lasting job conditions requiring high geographical mobility. Thus, whilst the proportion of persons who were mobile at both points is $4.7 \%$, the proportion of those who became mobile is $5.4 \%$, and the proportion of those who ceased to be mobile is $6.5 \%$. These patterns are consistent with one of the main findings of the analysis of the 2007 survey $^{62}{ }^{63}$, to wit: The number of persons who have high geographical job mobility at a given point in time is relatively low ( $16 \%$ on average in the six countries that participated in the project), but the number of persons who experience high geographical job mobility at some point in their life is high (52\%).

\section{Changes in subjective perceptions of well-being}

In 2011 most of the persons interviewed evaluated their individual wellbeing differently from in 2007. As can be observed in table 1 (column 6),

60 J.F. Hair, et al. Análisis multivariante ( $5^{a}$ Edición), (Madrid: Prentice Hall Iberia, 1999).

${ }^{61}$ We would like to thank Dr. Eva Median and Dr. Ramón Mahía of the Faculty of Economics and Business's ,Department of Applied Economics at the Universidad Autónoma de Madrid for their expert advice on the best statistical technique to choose for analysing these data.

${ }^{62}$ Schneider and Meil, Mobile Living Across Europe I. Relevance and Diversity of JobRelated Spatial Mobility in Six European Countries

${ }^{63}$ Lück, and Ruppenthal, «Insights into Mobile Living: Spread, Appearences and Characteristics» 


\section{Table 1}

Percentage of people who have changed the evaluation of their stress and satisfaction perceptions between both waves by type of mobility transition (weighted data)

\begin{tabular}{|c|c|c|c|c|c|c|}
\hline & & $\begin{array}{c}\text { Non-mobile } \\
\text { (rec. mob.) } \\
\text { in both } \\
\text { waves }\end{array}$ & $\begin{array}{l}\text { Recurringly } \\
\text { mobile in } \\
\text { both waves } \\
\text { ("stayer") }\end{array}$ & $\begin{array}{l}\text { Recurring } \\
\text { mobility } \\
\text { ended } \\
\text { (“stopper") }\end{array}$ & $\begin{array}{l}\text { Recurring } \\
\text { mobility } \\
\text { started } \\
\text { ("starter") }\end{array}$ & Total \\
\hline \multirow{3}{*}{$\begin{array}{l}\text { Change in } \\
\text { stress because } \\
\text { of work (1) }\end{array}$} & decreased & $32.4 \%$ & $27.8 \%$ & $39.8 \%$ & $33.3 \%$ & $32.7 \%$ \\
\hline & no change & $36.8 \%$ & $38.0 \%$ & $33.3 \%$ & $25.3 \%$ & $36.0 \%$ \\
\hline & increased & $30.8 \%$ & $34.2 \%$ & $26.9 \%$ & $41.3 \%$ & $31.4 \%$ \\
\hline \multicolumn{2}{|l|}{ Total } & $100.0 \%$ & $100.0 \%$ & $100.0 \%$ & $100.0 \%$ & $100.0 \%$ \\
\hline \multicolumn{2}{|l|}{ Number of cases } & 1100 & 81 & 92 & 75 & 1348 \\
\hline \multirow{3}{*}{$\begin{array}{l}\text { Change in } \\
\text { overall stress } \\
\text { (2) }\end{array}$} & decreased & $39.0 \%$ & $33.8 \%$ & $49.1 \%$ & $33.0 \%$ & $39.1 \%$ \\
\hline & no change & $19.8 \%$ & $26.3 \%$ & $15.2 \%$ & $20.2 \%$ & $19.8 \%$ \\
\hline & increased & $41.2 \%$ & $40.0 \%$ & $35.7 \%$ & $46.8 \%$ & $41.1 \%$ \\
\hline \multicolumn{2}{|l|}{ Total } & $100.0 \%$ & $100.0 \%$ & $100.0 \%$ & $100.0 \%$ & $100.0 \%$ \\
\hline \multicolumn{2}{|l|}{ Number of cases } & 1435 & 78 & 111 & 94 & 1718 \\
\hline \multirow{3}{*}{$\begin{array}{l}\text { Change in } \\
\text { satisfaction } \\
\text { with work ( } 3 \text { ) }\end{array}$} & decreased & $22.7 \%$ & $23.4 \%$ & $19.4 \%$ & $25.3 \%$ & $22.7 \%$ \\
\hline & no change & $55.5 \%$ & $59.7 \%$ & $49.5 \%$ & $54.7 \%$ & $55.3 \%$ \\
\hline & increased & $21.7 \%$ & $16.9 \%$ & $31.2 \%$ & $20.0 \%$ & $22.0 \%$ \\
\hline \multicolumn{2}{|l|}{ Total } & $100.0 \%$ & $100.0 \%$ & $100.0 \%$ & $100.0 \%$ & $100.0 \%$ \\
\hline \multicolumn{2}{|l|}{ Number of cases } & 1095 & 78 & 93 & 75 & 1341 \\
\hline \multirow{3}{*}{$\begin{array}{l}\text { Change in life } \\
\text { satisfaction (4) }\end{array}$} & decreased & $32.9 \%$ & $34.6 \%$ & $27.9 \%$ & $35.5 \%$ & $32.8 \%$ \\
\hline & no change & $34.7 \%$ & $37.0 \%$ & $36.9 \%$ & $29.0 \%$ & $34.6 \%$ \\
\hline & increased & $32.4 \%$ & $28.4 \%$ & $35.1 \%$ & $35.5 \%$ & $32.6 \%$ \\
\hline \multicolumn{2}{|l|}{ Total } & $100.0 \%$ & $100.0 \%$ & $100.0 \%$ & $100.0 \%$ & $100.0 \%$ \\
\hline \multicolumn{2}{|l|}{ Number of cases } & 1095 & 78 & 93 & 75 & 1341 \\
\hline
\end{tabular}

$\mathrm{V}=.107 . \mathrm{p}=.004(2) \mathrm{V}=.126 . \mathrm{p}=.009(3) \mathrm{V}=.081 . \mathrm{p}=.092(4) \mathrm{V}=.142 . \mathrm{p}=.000$.

Source: Panel data of the survey Job Mobilities and Family Lives in Europe. Modern Mobile Living and its Relation to Quality of Life, hosted in www.gesis.org.with reference number ZA5066 
only a limited proportion of persons reported the same levels of stress and satisfaction at both points in time. The greatest changes in the indicators of subjectively perceived well-being are registered in the general stress levels perceived during the three months prior to the interview $(80 \%$ of the persons interviewed reported a different stress level, as opposed to $20 \%$ who reported the same stress level at both points in time), whilst the smallest changes are registered in satisfaction with work (45\% as opposed to $55 \%$, respectively). Generally the greatest changes are observed in the stress indicators, whilst changes in satisfaction with work or with life in general are less frequent.

Furthermore, the proportion of persons who reported a decline in their subjective well-being, due to either an increase in their perceived stress level or a decrease in their satisfaction level, is similar to that of the persons who reported an increase in their subjective well-being. Thus, the proportion that declared an increase in their general stress level (41\% of the persons interviewed) is almost the same as that which declared a decrease (39\%). The same occurs with the assessment of satisfaction with life in general: The percentage reporting an increase in satisfaction is the same as the percentage that felt their satisfaction had decreased (32\% and 33\%, respectively). The same occurs when looking at evaluations of job-related stress and satisfaction. Altogether, therefore, no clear trend has been identified in the subjective well-being indicators considered during the period under analysis.

Changes in the geographical job mobility situation affect subjective personal well-being, as established in our first hypothesis. Differences in the various stress and satisfaction indicators according to transition type, i.e., according to whether the person is a starter or a stopper, are statistically significant for the levels conventionally accepted as valid (save in the case of differences in satisfaction with work). These differences, as can be observed in table 1, are not very high, however. In this sense, we stress that not only the persons who experienced a change in their mobility situation report different stress and satisfaction levels; those who do not have a job that requires high geographical mobility do the same.

The persons who have acquired high geographical job mobility during the analysed period frequently point to an increase in perceived stress levels, in both job-related stress $(41 \%)$ and general stress $(47 \%)$. This proportion is considerably higher than the proportion of those who report a decrease (33\% in both indicators) and also significantly higher than the proportion of persons who do not have a high-mobility job but also declare an increase in their stress levels ( $31 \%$ and $41 \%$, respectively). Therefore, having to accept high geographical job mobility generates an increase in stress levels in a high proportion of workers, although not in all cases. This confirms our second hypothesis. 
This stress increase, however, does not necessarily mean a substantial increase in dissatisfaction with life. In fact, the percentages of persons who accept high geographical mobility and are less satisfied with their work $(25 \%)$ or their life in general $(33 \%)$ are a minority. In addition, their percentages are no greater than those of the persons who have not had to accept high geographical mobility (23\% and 33\%, respectively). These results suggest, therefore, that despite the increase in stress in most cases the costs of having to accept greater geographical mobility are offset or even overbalanced by the advantages.

Persons who no longer have to accept high job mobility, however, as might be expected under our third hypothesis, tend in a higher proportion to declare that their stress levels have decreased, both in work-related stress (40\% so claim) and general stress (49\%). These percentages are appreciably higher than the comparison group, i.e., persons who do not have to accept high geographical job mobility (32\% and 39\%, respectively). Therefore, ending geographical mobility is associated with lower stress levels, confirming our hypothesis at least partially. The effects on satisfaction are, as in the previous case, less obvious since, whilst the percentage of these workers who report an increase in satisfaction with work (31\%) and with life in general $(35 \%)$ is larger than the percentage reporting a decrease (19\% and $28 \%$, respectively), compared with non-mobiles the differences are not so important, especially in terms of satisfaction with life. The reason for this may be that stopping mobility can also entail a loss of the advantages stemming from mobility and/or mobility may have already been accepted as something normal and inherent in the job.

In the collective of workers who were mobile in both 2007 and 2011, the proportion of those who report an increase in stress levels is higher than that of those who report a decrease, in both stress from work $(34 \%$ as opposed to $28 \%$ ) and general stress (40\% as opposed to $34 \%$ ); but compared to non-mobiles there are no statistically significant differences. The same pattern can be observed as regards satisfaction with work and with life in general. These results suggest that having to accept longterm mobility is not necessarily associated with a continued increase in stress levels and continued erosion in satisfaction levels. This happens in around one out of three cases, but not in the rest. Therefore, it is not infrequent, but it is not the norm, either. In addition to the advantages stemming from mobility, there is probably also gradual adaptation to the disadvantages. This does not mean that persons with a job that requires high geographical mobility do not go through different phases and moods that lead them to different evaluations of their working and living conditions, but it does mean they do not stray very far from the pattern of other workers. 
Altogether, it is found that taking a job that involves having to accept high geographical mobility is associated with an increase in stress levels but not necessarily with a reduction in satisfaction levels, with either work or life in general. Stopping mobility tends, to the contrary, to reduce stress levels but not necessarily to increase satisfaction. Thus, the hypotheses we formulated in the first part of this paper are confirmed at least partially, in the sense that mobility transitions affect subjective personal well-being by decreasing SWB when a person has to accept high geographical mobility and increasing SWB when a person stops having high geographical mobility.

\section{Impact of geographical mobility on subjective well-being controlling for the effects of other life transitions and the benefits of geographical mobility}

As discussed above, changes in indicators of subjective well-being may obey many different circumstances, not just changes in working conditions, particularly geographical mobility. Furthermore, mobility entails not only costs, but also advantages that may offset the burdens ${ }^{64}$. Many of these advantages are directly or indirectly related with an increase in income. The results of the ordinary linear regression analysis controlling for the effects of transitions in partnership and parenthood situations, changes in subjective perception of health, changes in levels of satisfaction with available economic income and the gender of the interviewed person are given in tables 2 (stress indicators) and 3 (satisfaction indicators), which we discuss below.

The impact of high geographical work mobility transitions on stress indicators after controlling for the economic benefits of mobility (measured through variations in levels of satisfaction with financial situation) and the costs involved (measured in terms of health, but also if necessary in terms of negative effects on family life) are not clearly reflected in multivariate analysis. The levels of significance of the estimators of the impact of the various variables all lie above the conventionally accepted threshold of $5 \%(\mathrm{p}>0.05)$, so the null hypothesis that said variables have no influence on changes in stress level cannot be rejected. Nevertheless, in the case of the impact that starting mobility has on the general stress level, the level of significance lies below 0.10 , a threshold that is generally

${ }^{64}$ Rüger and Ruppenthal, «Advantages and Disadvantages of Job-Related Spatial Mobility», 69-93. 


\section{Table 2}

Ordinary Least Square Regression analysis of changes in stress perception between wave 1 and wave 2 (unweighted data)

\begin{tabular}{|c|c|c|c|c|c|}
\hline Stress because of work (1) & B & St. error & Beta & $\mathrm{t}$ & Sig. \\
\hline Constant & -.079 & .061 & & -1.299 & .194 \\
\hline Recurring mobile in both waves & .071 & .112 & .018 & .636 & .525 \\
\hline Recurring mobility ended & -.079 & .101 & -.022 & -.789 & .430 \\
\hline Recurring mobility started & .103 & .165 & .017 & .622 & .534 \\
\hline $\begin{array}{l}\text { Difference in satisfaction with fi- } \\
\text { nancial situation }\end{array}$ & .062 & .048 & .035 & 1.284 & .199 \\
\hline $\begin{array}{l}\text { Partnership in wave } 1 \text {, no partner- } \\
\text { ship in wave } 2\end{array}$ & -.026 & .169 & -.004 & -.156 & .876 \\
\hline $\begin{array}{l}\text { No partnership in wave1, partner- } \\
\text { ship in wave } 2\end{array}$ & -.022 & .153 & -.004 & -.143 & .887 \\
\hline No child in w1, child in w2 & .034 & .146 & .006 & .234 & .815 \\
\hline Difference in health between wave & & & & & \\
\hline 1 and wave 2 & -.099 & .041 & -.066 & -2.407 & .016 \\
\hline Sex of respondent & .064 & .071 & .025 & .894 & .371 \\
\hline Overall stress (2) & B & St. error & Beta & $\mathrm{t}$ & Sig. \\
\hline Constant & -.202 & .111 & & -1.822 & .069 \\
\hline Recurring mobile in both waves & .204 & .213 & .023 & .954 & .340 \\
\hline Recurring mobility ended & -.098 & .178 & -.014 & -.551 & .582 \\
\hline Recurring mobility started & .489 & .296 & .040 & 1.649 & .099 \\
\hline $\begin{array}{l}\text { Difference in satisfaction with fi- } \\
\text { nancial situation }\end{array}$ & -.097 & .081 & -.029 & -1.191 & .234 \\
\hline $\begin{array}{l}\text { Partnership in wave } 1 \text {, no partner- } \\
\text { ship in wave } 2\end{array}$ & .149 & .290 & .012 & .514 & 607 \\
\hline No partnership in wave1, partner- & & & & & \\
\hline ship in wave2 & -.315 & .275 & -.028 & -1.144 & .253 \\
\hline No child in w1, child in w2 & -.090 & .263 & -.008 & -.344 & .731 \\
\hline Difference in health between wave & & & & & \\
\hline 1 and wave 2 & -.406 & .071 & -.137 & -5.715 & .000 \\
\hline Sex of respondent & .128 & .126 & .025 & 1.021 & .307 \\
\hline
\end{tabular}

$\mathrm{F}=1.125 . \mathrm{p}=.341 ;$ Rsquare $=.008(2) \mathrm{F}=4.609 . \mathrm{p}=.000 ;$ Rsquare $=.024$.

Source: Panel data of the survey Job Mobilities and Family Lives in Europe. Modern Mobile Living and its Relation to Quality of Life, hosted in www.gesis.org.with reference number ZA5066

considered acceptable for relatively small samples (such as this). This lack of significance also affects the other estimators of the impact of other transitions, such as family transitions (loss of partner and entry into 
partnership or parenthood), and change in financial situation. The only variable that appears as clearly significant is change in the subjective perception of health, in the sense that the perception of loss of health is associated with higher levels of stress ${ }^{65}{ }^{66}$, even at work, and vice-versa. The sex of the respondent doesn't appear either as significant.

The interpretation that can be made of these results is that, first, many other circumstances besides mobility exist that condition perceived levels of stress. Furthermore, mobility's impact on stress levels seems to hinge largely on the impact mobility has on personal health, such that the greater burdens attached to mobility can prove less stressful if they do not have negative effects on health and, more generally, on other dimensions of personal life. Nonetheless, whilst the levels of significance lie above the value conventionally accepted as valid, the signs of the estimators of the impact of mobility are consistent with the hypotheses and with the bivariate analysis given in the section above, i.e., starting high mobility is associated with an increase in stress levels, and stopping is associated with a decrease in stress levels, as is consistent with the literature ${ }^{67} 6869$. The signs of the other estimators are also consistent with what might normally be expected. If the sample were larger, the estimators would very likely be significant for the conventionally accepted levels, which would indicate that, despite the potential benefits, high geographical mobility tends to generate an increase in the stress levels with which people have to cope.

Unlike what was found in the bivariate analysis, the impact on satisfaction with work, on the contrary, does appear quite clear once the effects of other relevant variables are controlled, and it runs in the direction established by our working hypotheses. Despite the fact that the levels of significance are slightly above the conventional $\mathrm{p}<0.05$, it can be asserted that starting high geographical mobility is associated with a decrease in satisfaction with work, whilst stopping high geographical mobility is associated with an increase in satisfaction with work. Furthermore, over time, remaining at a job with high mobility also entails a reduction in satisfaction with work. This negative impact of geographical mobility is independent of the impact of the other variables considered, but it

${ }^{65}$ Hansson et al., «Relationship between commuting and health outcomes in a crosssectional population survey in southern Sweden»

${ }^{66}$ Rüger et al., «Fernpendeln und gesundheit. Gibt es Hinweise auf einen „healthy commuter effect?»: 113 $55-61$.

${ }^{67}$ Häfner, Kordy and Kächele, «Psychosozialer Versorgungsbedarf bei Berufspendlern»,

${ }^{68}$ Novaco and Gonzales, «Commuting and well-being», 174-205.

69 Turcotte, «Commuting to work: Results of the 2010 General Social Survey». 


\section{Table 3}

Ordinary Least Square Regression analysis of changes in satisfaction between waves one and two (unweighted data)

\begin{tabular}{|c|c|c|c|c|c|}
\hline Satisfaction with work (1) & B & St. error & Beta & $\mathrm{t}$ & Sig. \\
\hline Constant & -.009 & .037 & & -.246 & .805 \\
\hline Recurring mobile in both waves & -.118 & .069 & -.047 & -1.713 & .087 \\
\hline Recurring mobility ended & .112 & .061 & .050 & 1.828 & .068 \\
\hline Recurring mobility started & -.195 & .101 & -.053 & -1.924 & .055 \\
\hline $\begin{array}{l}\text { Difference in satisfaction with fi- } \\
\text { nancial situation }\end{array}$ & .212 & .030 & .192 & 7.145 & .000 \\
\hline $\begin{array}{l}\text { Partnership in wave1, no partner- } \\
\text { ship in wave } 2\end{array}$ & -.210 & .104 & -.054 & -2.012 & .044 \\
\hline $\begin{array}{l}\text { No partnership in wave1, partner- } \\
\text { ship in wave } 2\end{array}$ & -.064 & .094 & -.019 & -.682 & .495 \\
\hline No child in w1, child in w2 & .011 & .089 & .003 & .127 & .899 \\
\hline Difference in health between wave & & & & & \\
\hline $\begin{array}{l}1 \text { and wave } 2 \\
\text { Sex of respondent }\end{array}$ & $\begin{array}{l}.005 \\
.023\end{array}$ & $\begin{array}{l}.025 \\
.044\end{array}$ & $\begin{array}{l}.005 \\
.015\end{array}$ & $\begin{array}{l}.204 \\
.536\end{array}$ & $\begin{array}{l}.838 \\
.592\end{array}$ \\
\hline Satisfaction with life (2) & B & St. error & Beta & $\mathrm{t}$ & Sig. \\
\hline Constant & .021 & .077 & & .273 & .785 \\
\hline Recurring mobile in both waves & -.058 & .148 & -.009 & -.389 & .697 \\
\hline Recurring mobility ended & .075 & .124 & .015 & .607 & .544 \\
\hline Recurring mobility started & -.385 & .206 & -.045 & -1.870 & .062 \\
\hline $\begin{array}{l}\text { Difference in satisfaction with fi- } \\
\text { nancial situation }\end{array}$ & .283 & .056 & .119 & 5.016 & .000 \\
\hline $\begin{array}{l}\text { Partnership in wave1, no partner- } \\
\text { ship in wave } 2\end{array}$ & -1.010 & .200 & -.120 & -5.046 & .000 \\
\hline $\begin{array}{l}\text { No partnership in wave1, partner- } \\
\text { ship in wave } 2\end{array}$ & .304 & .191 & .038 & 1.591 & .112 \\
\hline No child in w1, child in w2 & .038 & .183 & .005 & .206 & .837 \\
\hline Difference in health between wave & & & & & \\
\hline 1 and wave 2 & .239 & .049 & .115 & 4.835 & .000 \\
\hline Sex of respondent & .034 & .087 & .009 & .388 & .698 \\
\hline
\end{tabular}

$\mathrm{F}=7.623 . \mathrm{p}=.000 ;$ Rsquare $=.009(2) \mathrm{F}=9.686 . \mathrm{p}=.000 ;$ Rsquare $=.049$.

Source: Panel data of the survey Job Mobilities and Family Lives in Europe. Modern Mobile Living and its Relation to Quality of Life, hosted in www.gesis.org.with reference number ZA5066

is relatively limited compared with the impact of changes in levels of satisfaction with the financial situation, as can be observed in the values of the estimated beta coefficients. In fact, whilst entering mobility entails 
an increase in satisfaction with the financial situation, the negative effects on satisfaction with work are neutralised by the economic improvement; what is more, if the increase in satisfaction is substantial (more than a full point), satisfaction with work increases. Now, if mobility does not entail increases in financial satisfaction over time, satisfaction with work decreases, because the persons who are mobile at both points in time report a reduced level of satisfaction with work except where it is offset by increases in their level of satisfaction with their financial situation. Stoppers tend to increase their satisfaction with work, except where stopping entails a worsening of their satisfaction with their financial situation. The economic benefits of geographical mobility therefore condition the bottom line of satisfaction with working conditions and job characteristics. The bivariate analysis reported in the section above, in which mobility is not recorded as having a clear negative effect on satisfaction with work, evinces that generally the economic benefits stemming from accepting high geographical mobility tend to be offset by the costs in terms of satisfaction with work, so the majority of mobile persons did not change their level of satisfaction with work or even increased it.

The effects on satisfaction with life in general do not show directly, because the estimators for the different geographical mobility situations are not significant for the conventionally accepted level of significance, $p<0.05$. Nevertheless, the sign of the estimators points in the direction of our initial hypotheses. This suggests that if the sample size were larger the estimators would very probably be significant. The analysis performed in table 3 shows that changes in levels of satisfaction with work, financial situation and health and transitions in family biography (i.e., changes in the fundamental dimensions of a person's life) do influence changes in satisfaction with life. From our point of view these results show that the effects of geographical mobility transitions on subjective well-being are conditioned by the advantages and drawbacks the transitions provide for individuals $^{70} 71$. Where geographical mobility entails greater dissatisfaction with work, has a negative effect on health or hampers life projects (as where it is cause for divorce or prevents parenthood plans from going through), geographical job mobility negatively affects satisfaction with life; but if that is not the case, or if the costs involved in these dimensions or others (lack of time or fewer social relations ${ }^{72}$ ) are offset by the benefits of increased

70 Meil, «Movilidad geográfica en las biografías laborales: alcance, características y razones para asumirla».

71 Rüger and Ruppenthal, «Advantages and Disadvantages of Job-Related Spatial Mobility», 69-93.

72 Meil, «Movilidad geográfica en las biografías laborales: alcance, características y razones para asumirla». 
geographical job mobility (primarily an increase in financial satisfaction), geographical mobility does not necessarily have to have a negative effect on satisfaction with life or, more generally, subjective personal wellbeing. This effect is valid both for men and for women who are involved in mobility transitions as there are no significant differences according to the sex of the respondent. The analysis we perform doesn't contradicts the well established result that women are less prone to engage in job mobility ${ }^{73}$, as it is focused on satisfaction levels.

\section{Conclusions}

Delocalisation of the production process and flexibilisation of employer/ employee relations, amongst other factors, have placed growing demands for geographical mobility on the working population, making travel over greater distances necessary in order to balance work and family life, get a job or advance career-wise ${ }^{74}{ }^{75}$. Geographical mobility has taken a great many forms apart from migration; it also includes forms of circular mobility that involve long commutes and/or trips so long that workers cannot go home at the end of the working day, forcing them to stay away from home overnight for long periods and/or frequently 767778 . Acceptance of working conditions that require high circular geographical mobility depends on the advantages and drawbacks entailed. In this paper we have focused on the impact that job mobility has on subjective personal well-being, and we have done so from a longitudinal point of view, as we held panel data from two surveys conducted in 2007 and 2011 in four European countries. We were thus able to analyse the impact that starting, stopping and sustaining high circular geographical mobility has on the subjective well-being of working persons.

The concept of subjective well-being is a conceptual construct that has garnered increasing attention in the social sciences, particularly economics

73 Schneider and Meil, Mobile Living Across Europe I. Relevance and Diversity of JobRelated Spatial Mobility in Six European Countries.

${ }^{74}$ Manuel Castells, La era de la información: economía, sociedad y cultura (Madrid, Alianza editorial, 1997).

75 Sennett, The Corrosion of Character: the personal consequences of work in the new capitalism.

76 Schneider, Limmer and Ruckdeschel, Mobil, flexibel, gebunden: Familie und Beruf in der mobilen Gesellschaft.

77 Schneider and Meil, Mobile Living Across Europe I. Relevance and Diversity of JobRelated Spatial Mobility in Six European Countries.

78 Schneider and Collet, Causes and Consequences of Job-Related Spatial Mobility in Cross-National Comparison. 
and sociology, because it enables the well-being of persons and societies to be analysed from a more comprehensive viewpoint. Subjective well-being is a polysemic concept whose measurement has been attempted in various ways. This paper considered two dimensions of subjective well-being, stress and satisfaction with work and with life in general. Our objective was consequently to analyse the impact of circular geographical mobility transitions on these dimensions of subjective well-being.

In the analysed period, it is observed that most of the persons interviewed changed their assessment of their levels of stress and satisfaction with work and with life in general. These changes do not present a clear pattern toward an increase or decrease in subjective wellbeing; the proportion of persons reporting an increase is almost equal to the proportion of those declaring a decrease. Many are the factors that can influence these changes, and transitions in circular geographical mobility do exert some influence. Starting mobility is associated with an increase in levels of stress in work and in life in general, and stopping mobility is associated with a decrease in the same stress levels, whilst the effects on satisfaction with work or with life are not very evident. These effects, however, are limited, as the workers who report an increase in stress when starting mobility are a minority compared to those who declare a decrease or report no change at all. The same thing happens with those who report a decrease in their stress level due to stopping mobility.

When we control for other important life changes that decisively affect individual well-being, such as family transitions (to or from partnership and parenthood), changes in health, changes in economic situation (measured through changes in satisfaction with income levels) and sex of the respondent, the impact of job mobility on subjective well-being does not appear as clearly as might have been expected. This absence of a close, statistically clear relationship between high mobility and negative effects on subjective well-being may be due to a problem of sample insufficiency, since the phenomenon is not very widespread; if so, for a larger sample the effects would show as statistically significant in the expected direction, as the signs of the estimators indicate. On the other hand, however, it is also necessary to consider that for the persons involved mobility also has advantages and drawbacks that are reflected in these dimensions of personal life.

If a significance threshold of $\mathrm{p}<0.10$ is accepted as satisfactory, the analysis confirms our working hypotheses by showing that starting mobility generates stress and decreases satisfaction with work, both for men and women. Over time most people learn to handle the stress mobility generates as they adapt to it and accept it as normal. Thus, when they stop mobility, they do not necessarily report a substantial decrease in the perceived stress level, although they do report an increase in satisfaction with work. Lower 
satisfaction with work can be offset by the advantages stemming from mobility, particularly if those advantages mean an increase in satisfaction with the financial situation and have no substantial costs in terms of family plans or health. In this sense, if the balance of advantages and drawbacks of mobility is considered positive, the negative impact on subjective well-being can be neutralised or overpowered. Thus, improvements in financial support from the employer and effective plans on work-family balance for mobile worker, particularly flexitime, could reduce the impact of mobility on subjective wellbeing, in addition to a general support and understanding from the employer ${ }^{79}$. If we consider satisfaction with life as an overall indicator or summary of subjective well-being, as the literature frequently does, the impact of mobility transitions is not direct, but indirect (at least with the database with which we have worked), through the impact mobility has on satisfaction with work and with the financial situation, on health and on family plans.

\section{Bibliography}

Beck, Ulrich and Beck-Gernsheim, Elisabeth, Distant Love. Cambridge: Polity Press, 2013.

Castells, Manuel, La era de la información: economía, sociedad y cultura. Madrid, Alianza editorial, 1997.

Collet, Beate and Andrea Dauber (2010), «Gender and Job Mobility». In Causes and Consequences of Job-Related Spatial Mobility in Cross-National Comparison, edited by Norbert F. Schneider y Beate Collet, 173-194. Leverkusen: Barbara Budrich Publisher, 2010.

Costal, Giovanni, Laurie Pickup and Vittorio Di Martino «Commuting - a further stress factor for working people: evidence from the European Community», Int. Arch Occup Environ Heath 60-5 (1988): 377-385 doi:10.1007/BF00405674.

Diener, Ed, Eunkook M. Suh, Richard E. Lucas, y Heidi L. Smith, «Subjective well-being: Three decades of progress». Psychological Review 5-1 (1999): 1-31.

Dolan, Paul, Tessa Peasgood, and Mathew White, «Do we really know what makes us happy? A review of the economic literature on the factors associated with subjective wellbeing». Journal of Economic Psychology, 29-1 (2008): 94-122.

Eurofound, Third European Quality of Life Survey - Quality of life in Europe: Subjective well-being. Luxembourg: Publications Office of the European Union, 2013.

Faulconbridge, James R. and Jonathan V. Beaverstock, «Geographies of international business travel in the professional service economy». In Mobility

79 Gerardo Meil, Luis Ayuso and Ramón Mahía, «Support for Job Mobile People and Their Adaptation to Mobility» in Causes and Consequences of Job-Related Spatial Mobility in Cross-National Comparison, ed. by Norbert F. Schneider and Beate Collet (Leverkusen: Barbara Budrich Publisher, 2010), 319-338. 
and Technology in the Workplace, edited by Donald Hislop, 87-102. London and New York: Routledge, 2008.

Feldhaus, Michael and Monika Schlegel, «Job-Related Circular Mobility and the Quality of Intimate Relationships». Comparative population studies 38-2 (2013): 291-314.

Häfner, Steffen, Hans Kordy and Horst Kächele, «Psychosozialer Versorgungsbedarf bei Berufspendlern». Psychotherapie Psychosomatik medizinische Psychologie 51 (2001): 55-61.

Hair, J.F., R.E. Anderson, R.L. Tatham and W.C. Black, Análisis multivariante (5. ${ }^{a}$ edición). Madrid: Prentice Hall Iberia, 1999.

Hansson, Erik, Kristoffer Mattisson, Jonas Björk, Per Olof Östergren and Kristina Jakobsson, «Relationship between commuting and health outcomes in a crosssectional population survey in southern Sweden». BMC Public Health 11 (2011):834-842, doi: 10.1186/1471-2458-11-834.

Haynes, Paul, «Information and Communication Technology and International Business Travel: Mobility Allies?». Mobilities 5-4 (2010): 547- 563, doi:10.108 0/17450101.2010.510337

Jeong, Yu-Jin, Anisa M. Zvonkovic, Yoshie Sano and Alan. C. Cock «The occurrence and frequency of overnight job travel in the USA». Work, employment and society 27-1 (2013): 138-152, doi: 10.1177/0950017012460328

Koslowsky, Meni, Avraham Kluger and Mordechai Reich, Commuting Stress. Causes, Effects, and Methods of Coping. New York: Plenum Press, 1995.

Limmer, Ruth and Heiko Rüger, «Job Mobilities and Quality of Life». In Causes and Consequences of Job-Related Spatial Mobility in Cross-National Comparison, edited by Norbert F. Schneider y Beate Collet, 263-288. Leverkusen: Barbara Budrich Publisher, 2010.

Lück, Detlev, and Silvia Ruppenthal, «Insights into Mobile Living: Spread, Appearences and Characteristics». In Causes and Consequences of Job-Related Spatial Mobility in Cross-National Comparison, edited by Norbert F. Schneider and Beate Collet, 37-65. Leverkusen: Barbara Budrich Publisher, 2010.

Meil, Gerardo, «Job Mobility and Family Life». In Causes and Consequences of Job-Related Spatial Mobility in Cross-National Comparison, edited by Norbert F. Schneider y Beate Collet, 215-235. Leverkusen: Barbara Budrich Publisher, 2010.

Meil, Gerardo, Luis Ayuso and Ramón Mahía, «Support for Job Mobile People and Their Adaptation to Mobility». In Causes and Consequences of Job-Related Spatial Mobility in Cross-National Comparison, edited by Norbert F. Schneider and Beate Collet, 37-65. Leverkusen: Barbara Budrich Publisher, 2010.

Meil, Gerardo, «Movilidad geográfica en las biografías laborales: alcance, características y razones para asumirla». Revista del Ministerio de Empleo y Seguridad Social 111 (2014): 17-35.

Nitsche, Dorothea, Heiko Rüger, Stephan Letzel, Eva Münster, «Berufspendeln und Fehlzeiten. Fehlen Berufspendler häufiger bei der Arbeit? » Arbeitsmedizin Sozialmedizin Umweltmedizin 44-3 (2009): 162- 171.

Novaco, Raymond W. and Oscar I. Gonzales, «Commuting and well-being». In Technology and well-being, edited by Yair. Amichai-Hamburger, 174-205. New York: Cambridge University Press, 2009. 
Olsson, Lars, Tommy Gärling, Dick Ettema, Margareta Friman and Satoshi Fujii, «Happiness and Satisfaction with Work Commute». Social Indicators Research 111, (2013): 255-263, doi:10.1007/s11205-012-0003-2

Rapley, Mark, Quality of life research, A critical introduction. London: Sage, 2003. Roller, Katrin, «Corporate Mobility: When and Why Does it Become a Burden?». In Sustainable Mobility in Metropolitan Regions edited by Gebhard Wulfhorst and Stefan Klug, 65-82. Wiesbaden: Springer, 2016.

Rüger, Heiko, Dorothea Nitsche, Stephan Letzel and Eva Münster, «Fernpendeln und gesundheit. Gibt es Hinweise auf einen healthy commuter effect?», Arbeitsmedizin Sozialmedizin Umweltmedizin, 44-3 (2009): 113.

Rüger, Heiko and Silvia Ruppenthal, «Advantages and Disadvantages of JobRelated Spatial Mobility». In Causes and Consequences of Job-Related Spatial Mobility in Cross-National Comparison, edited by Norbert F. Schneider y Beate Collet, 69-93. Leverkusen: Barbara Budrich Publisher, 2010.

Rüger, Heiko, Katharina Micheel, Thomas Skora and Silvia Ruppenthal, «Sind berufsbedingte räumliche Mobilität und freiwilliges Engagement miteinander vereinbar? Befunde der zweiten Erhebungswelle der Studie „Job Mobilities and Family Lives in Europe“" , Bevölkerungsforschung Aktuell 33-6 (2012): 2-9.

Rüger, Heiko, Simon Pfaff, Thomas Skora, Norbert F. Schneider, Job Mobilities and Family Lives in Europe - Second Wave. Panel Data Set \& Oversampling. Wiesbaden: Bundesinstitut für Bevölkerungsforschung, 2016.

Sennett, Richard, The Corrosion of Character: the personal consequences of work in the new capitalism. New York: Norton, 1998.

Schneider, Norbert F., Ruth Limmer and Kerstin Ruckdeschel, Mobil, flexibel, gebunden: Familie und Beruf in der mobilen Gesellschaft. Frankfurt am Main: Campus Verlag, 2002.

Schneider, Norbert F. and Gerardo Meil, Mobile Living Across Europe I. Relevance and Diversity of Job-Related Spatial Mobility in Six European Countries. Opladen/Farmington Hills: Barbara Budrich Publishers, 2008.

Schneider Norbert F. and Beate Collet, Causes and Consequences of Job-Related Spatial Mobility in Cross-National Comparison. Leverkusen: Barbara Budrich Publisher, 2010.

Stiglitz, Joseph, Amartia Sen, and Jean-Paul Fittousi, Report by the Commission on the Measurement of Economic Performance and Social Progress. Paris, 2009. Available in http://www.stiglitz-sen-fitoussi.fr/en/index.htm.

Stutzer, Alois and Bruno S. Frey, «Stress that doesn't pay. The commuting paradox», The Scandinavian Journal of Economics 110-2 (2008): 339-366 doi: 10.1111/j.1467-9442.2008.00542.x.

Turcotte, Martin, «Commuting to work: Results of the 2010 General Social Survey», Statistics Canada Catalogue no. 11-008-X. 2011. Available in http:// www.statcan.gc.ca/pub/11-008-

Vincent-Geslin,Stephanie and Emmanuel Ravalet, (2016), «Determinants of Extreme Commuting. Evidence from Brussels» Journal of Transportation Geography 54 (2016):240-247, doi:10.1016/j.jtrangeo.2016.06.013. 


\section{Derechos de autor}

Los derechos de autor (para la distribución, comunicación pública, reproducción e inclusión en bases de datos de indexación y repositorios institucionales) de esta publicación (Cuadernos Europeos de Deusto, CED) pertenecen a la editorial Universidad de Deusto. El acceso al contenido digital de cualquier número de Cuadernos Europeos de Deusto es gratuito, transcurridos 6 meses desde su publicación. Los trabajos podrán descargarse, copiar y difundir en cualquier medio sin fines comerciales y según lo previsto por la ley; sin la previa autorización de la Editorial (Universidad de Deusto) o el autor. Así mismo, los trabajos editados en CED pueden ser publicados con posterioridad en otros medios o revistas, siempre que el autor indique con claridad y en la primera nota a pie de página que el trabajo se publicó por primera vez en $C E D$, con indicación del número, año, páginas y DOI (si procede). Cualquier otro uso de su contenido en cualquier medio o formato, ahora conocido o desarrollado en el futuro, requiere el permiso previo por escrito del titular de los derechos de autor.

\section{Copyright}

Copyright (for distribution, public communication, reproduction and inclusion in indexation databases and institutional repositories) of this publication (Cuadernos Europeos de Deusto, CED) belongs to the publisher University of Deusto. Access to the digital content of any Issue of Cuadernos Europeos de Deusto is free only six months after its publication. The content can be accessed, downloaded, copies, and distributed freely in any medium only for non-commercial purposes and in accordance with any applicable copyright legislation, without prior permission from the copyright holder (University of Deusto) or the author. Thus, the content of $C E D$ can be subsequently published in other media or journals, as long as the author clearly indicates in the first footnote that the work was published in $C E D$ for the first time, indicating the Issue number, year, pages, and DOI (if applicable). Any other use of its content in any medium or format, now known or developed in the future, requires prior written permission of the copyright holder. 